\title{
Okul Yöneticilerinin Eğitimde Yaratıcı Drama Etkinliklerine İlişkin Tutumları İçin Bir Ölçek Geliştirme Çalışması*
}

\author{
Mustafa Otrar ${ }^{1}$
}

Adnan Çöme²

$\ddot{O z}$ zet

Bu araştırma, ilköğretim okulu yöneticilerinin eğitimde yaratıcı drama etkinliklerine yönelik tutumlarını belirlemek amacıyla gerçekleştirilmiştir. Bu bă̆lamda, Ĕgitimde Yaratıcı Drama Etkinliklerine Yönelik Tutum Ölçeği (YDT) adlı bir tutum ölçeği geliştirilmiştir. Çalışmaya 37 madde ile başlanmış ve uygulamalar 300 okul yöneticisi üzerinde gerçekleştirilmiştir. Açımlayıcı faktör analizi ile maddelerin toplam 4 faktörde toplandiğı, açıklanan toplam varyans miktarının yaklaşık \%61,77 olduğu, faktörler arasında anlamlı korelasyonların olduğu belirlenmiştir. Madde-toplam ve madde-kalan korelasyonları anlamlı ve maddelerin ayırt edici olduğu da saptanmıştır. Çalışma sonucunda Cronbach's Alpha katsayısı faktörler arasında $\alpha=, 712-\alpha=, 921$ arasında değişmektedir. Ölçek toplamı içinse alfa,909 olarak hesaplanmıştır. Test-tekrar test korelasyonları ise tüm faktörler (rmin=,651; $p<, 001 /$ rmax=,863; $p<, 001)$ ve ölçek toplam puanı için $(r=, 826 ; p<, 001)$ anlamlı bulunmuştur.

Anahtar sözcükler: Yaratıcı drama, ĕgitimde yaratıcı drama, okul yöneticileri, tutum ölçeği

\section{The Work of Scale Development of School Directors about TheirAttitudes Related to Creative Drama Activities in School Education}

\begin{abstract}
This survey has been realized to pinpoint the attitudes and manners of the primary school administrators' as for the creative drama activities in education. In this respect, a manner scale has been developed: "The attitude scale as for the Creative Drama Activities in Education." The survey has been set on the 37 item and the applications have been fulfilled over 300 school administrators. All items have been classified under 4 factors using the exploratory factor analysis. And, it has been pointed out that the given total variance is about \%61,77 and thus, there has been significant correlations among factors. It has been displayed that the items were discriminating and the item-total and item-reminder correlations were significant. At the end of the survey, Cronbach's Alpha coefficient has been calculated as $\alpha=, 909$ for scale also alpha coefficient among the factors ranges from $\alpha=, 712$ to $\alpha=, 921$. Test-retest correlations has been found significant for all factors $($ rmin $=, 651 ; p<, 001 / r \max =, 863 ; p<, 001)$ and scale total point $(r=, 826 ; p<, 001)$.
\end{abstract}

Key Words: Creative drama, creative drama in education, school managers, attitudes scale

\footnotetext{
* Bu makale" Okul Yöneticilerinin Eğitimde Yaratıcı Drama Faaliyetlerine İlişkin Tutumları "isimli yüksek lisans tezinden üretilmiştir.

1 Dr.,. Marmara Üniversitesi Atatürk Eğitim Fakültesi Eğitim Bilimleri Bölümü,motrar@marmara.edu.tr

2 Öğretmen, Milli Eğitim Bakanlığı, adnancome@gmail.com
} 


\section{Giriş}

Yaratıcı drama, birçok alanda kullanılabilen bir yöntemdir. Türkçe, tarih, coğrafya, matematik, psikoloji gibi temel derslerin yanı sıra ekonomi, politika, endüstri, insan ilişkileri gibi alanlarda da yaratıcı drama çalışmalarına rastlanmaktadır. Yaratıcı drama; sanat eğitimi, öğretmen eğitimi, drama öğretmeninin eğitimi, polis eğitimi, asker eğitimi, aşçı eğitimi gibi alanlarda ve ayrıca problem çözme yöntemlerinin eğitiminde de kullanılmaktadır (Fulford, Hutchings, Shmitz, 2001). Eğitimsel bir pencereden bakıldığında; "Yaratıcı drama, doğaçlama, rol oynama vb. tiyatro ya da drama tekniklerinden yararlanılarak, bir grup çalışması içinde, bireylerin bir yaşantıyı, bir olayı, bir fikri, kimi zaman bir soyut kavramı ya da bir davranışı, eski bilişsel örüntülerin yeniden düzenlenmesi yoluyla ve gözlem, deneyim, duygu ve yaşantıların gözden geçirildiği “oyunsu” süreçlerde anlamlandırması, canlandırmasıdır." (San, 1991).

San (1989), yaratıcı dramanın eğitimde kullanılmasıyla ilgili olarak dramanın öğrenmeye ve varılan bilgilerin gözden geçirilmesi, irdelenmesi, farklı perspektiflerden tekrar ele alınması suretiyle yeniden yapıland1rılmasına zemin hazırlandığını, bu nedenlerden ötürü yaratıcı dramanın eğitimde mutlaka kullanılmasının gerektiğini ifade etmektedir. Yaratıcı drama, bireyin eğitiminde ve öğrenmesinde isteklilik sağlayacak bir yöntemdir. Yaratıcı drama sayesinde insanda empati yeteneği gelişir, birey yaşamında kendini rahatlıkla ifade edebilecek duruma gelir ve yaratıcılığı gelişerek yaşama çok yönlü bakmaya başlar. Birey, eğitim öğretim ortamında aktiftir ve araştırma duygusu gelişmiş bir vaziyettedir (Güneysu, 1991).

Önemli bir öğrenme yolu olan yaratıcı drama, bireysel ve toplumsal sorunların üzerinde düşünülmesine de yardım eder. Olaylar ve durumlar arasında bağlantı kurulmasını sağlar (O’Neill \& Lambert, 1989; Akt: Üstündağ, 1994). Yaratıcı drama, öğrenmelerin gerçekleşmesinde etkileşimli ortamlar hazırlanması bakımından önemli bir yöntemdir. Aktif eğitim ortamlarında öğrencilerin kolektif bir çalışma ve işbirliğine dayalı öğrenme durumlarını kullanmakla, öğrenmelerinde ve bilgileri anlamlandırmalarında çağdaş yaklaşımların çoğunun uyum gösterdiği bilinmektedir. Nitekim Myers ve Philbin (1991) eğitimdeki yeni yaklaşımların öğretmen ve öğrencilerin karşılıklı ilişkilerinde problem çözme aşamalarını gerçekleştirdiği ve eleştirel düşünme yetilerine olanaklar sunduğundan dramayı önemli gördüklerini ifade etmektedirler (Myers \& Philbin, 1991; Akt: Üstündağ, 1994). Okvuran (1994) yaratıcı dramada yaratılan her durumun bir imgelem, yani hayal ürünü olduğunu ve kurgusal bir nitelik taşıdığını, drama oynayanların büyük bir haz duygusu tattıklarını ve bu hazzın ise yaratıcılıktan dolayı estetik bir haz olduğunu ifade etmektedir. Bireyin haz duyacağı bir ortamda bulunması şüphesiz ki öğrenmelerin gerçekleşmesi adına önemli bir adımdır. Çünkü baskılarla donanmış, otoriter ve zorlayıcı bir eğitim ortamının aksine böylesi heyecan ve haz duygularını tadabileceği bir ortamda birey, kendini rahatça ifade edebilecek, bunun sonucunda kendini gerçekleştirebilecek, ortaya özgün ve yaratıcı öğelerle donanmış ürünler ortaya koyabilecek, aktif yaşantıların içinde özgüven duygusu kazanabilecektir. Birey özgüven kazandıkça, bir kısım kalıp ve kuralların dışına çıkmayı başarıp, geniş perspektiften bakarak yaratıcı unsurları kazandıkça ve kendini rahatça ifade edebileceği bağımsız ve özgür ortamlarda dile geldikçe haz duyması kaçınılmazdır.

Yaratıcı drama, öğrenmenin temel süreçlerinden olan bilişsel süreçlerin yanında, duyuşsal ve devinişsel süreçlere de hizmet etmektedir. Nitekim bu konuda Rosenberg (1981) yaratıcı dramanın bir öğrenme yolu olarak en önemli varlığının zihinsel, sosyal ve psikomotor yeteneklerle bütünleşmiş olduğunu belirtir. Birçok öğrenme şeklinde varılan becerilerin dramaya katılımla elde edilebileceğini ifade eder (Rosenberg, 1981; Akt; Ömeroğlu, 1990). Yaratıcı dramayla katılımcılar hayal güçlerini geliştirme, bağımsız düşünebilme, işbirliği yapabilme ve sosyal duyarlılık yaratma, duyguların kontrolü, dil gelişimi ve etkili konuşma gibi bir kısım değerler kazanırlar. Yaratıcı drama, grubun kendini geliştirmesi için firsatlar sunar. Fikirlerin geliştirilmesi ve problemlerin çözülebilmesine olanak tanır (Adıgüzel, 1994). Nitekim San (1990), drama uygulamaları içerisinde kişinin etkileşim sağlama ve sosyalleşme ile birlikte kendine güven ve saygıyı geliştirdiğini, bir gruba ait olma 
duygularının bireye güç verdiğini, iletişim ve problem çözme yetilerinin gelişmesinin ise dramanın önemli boyutlarından olduğunu ifade etmiştir.

Bir yöntem olarak yaratıcı dramaya yönelik yapılan çalışmalarda, farklı alanlarda, yaş gruplarında ve düzeylerde tutumlara bakılmıştır. Ancak yönetici alanında yöntemin yansımaları yenidir ve yönetici alanında farklı düzey ve yaş gruplarında dramaya yönelik tutumlar merak konusudur. Bilimsel tutum ve bilimsel süreç becerilerine sahip olması gereken (Özbilgin, 1989; Akt: Güner \& diğ., 1999) nitelikli bir okul yöneticisinin, model olabilecek olumlu kişilik özelliklerini de benimsediğinde ki, yaratıcı drama yöntemi mesleki beceri ve kişilik özelliklerini desteklemektedir (Yeğen, 2004), eğitim süreci içerisinde etkili olması kaçınılmazdır.

Öğretmen adaylarının ve de araştırmanın objesi olması bakımından okul yöneticisi adaylarının, aktif öğrenci merkezli yaratıcı drama uygulamalarını üniversite düzeyinde alıyor olmaları onların mesleki ve kişisel kimliklerine katkı sağlamakla birlikte, öğrendikleri bu yöntemi ilköğretim düzeyinde uygulayacak olmaları da alternatif bir yöntem olarak dikkat çekmektedir. Özellikle okul yönetimindeki yansımalarının yeni yeni hayat uygulayacak olmaları da önem taşımaktadır. Bulduğu yatatıcı drama çalışmalarının öğrencinin yaparak yaşayarak öğrenmelerine firsatlar tanıması, dahası öğrencilerin zevkli ve eğlenceli bir ortam olarak tanımladıkları uygulamalar ile öğreniyor olmaları, böyle bir yöntemin kullanılıp kullanılmayacağına yönelik ilgi ve alakaları artırmaktadır. Okul yöneticilerinin üniversite düzeyinde yönteme yönelik geliştirecekleri tutum, yöntemin mesleki hayatta kullanılıp kullanılmayacağına yönelik önemli bir adım olacaktır. Çünkü oluşturulan tutumlar uzun sürede oluşmaktadır ve hepsinden önemlisi kalıcıdır (Sherif ve Sherif, 1996). Değerlendirilmesi gereken bir diğer boyut ise tutumların öğrenmeler üzerindeki etkisinin olması ve ilköğretim düzeyindeki öğrenmeler için öğretmen nitelikleri ve kullanılan öğretim yönteminin, öğrenci tutumlarını doğrudan ilgilendirdiği gerçeğidir. Bir başka deyişle okul yöneticilerinin öğrenmelerinde öğrencilerin tutumları önemlidir. Öğrencilerin öğrenmeleri üzerinde etkili olan derse yönelik tutumlar öğretmen nitelikleri ve kullanılan öğretim yönteminden etkilenmektedir (Çakır, Şahin ve Şahin, 2000).

O halde okullarda yaratıcı drama etkinliklerinin uygulanmasında yöneticiler önemli bir rol oynamaktadır. Yönetici yaklaşımları özellikle uygulamalarda karar mekanizmalarının işletilmesinde, personelin eş güdümlenmesinde, eğitim ortamlarının uygun biçimde düzenlenmesi ve denetlenmesinde etkilidir. Eğitici drama etkinliklerinin belirleyici olan bir diğer yönetici özelliği de yöneticilerin söz konusu etkinlere ilişkin algılayış ve tutumlarıdır. Eğitimde yaratıcı drama etkinliklerin kullanımı bir boyutu ile eğitim yöneticisinin tutumundan etkilenecektir. Olumlu tutum sahibi olan yöneticilerinin tavırları, okul imkanlarının kullanılması ve personelin bu etkinlikleri kullanması konusunda özendirilmesi açısından önemlidir.

$\mathrm{Bu}$ sebeple, çalışmanın teorik içeriği ve okullarda uygulanan yaratıcı drama etkinlikleri ile okul yöneticilerinin bu faaliyetlere ilişkin tutumları arasında bir ilişki kurmaya yönelim açısından, okullarda meydana gelen yaratıcı dramaların uygulanması, yaratıcı dramaların sonuçlandırılması ve değerlendirilmesi ile ilgili özel ve devlete bağlı ilköğretim okullarındaki okul yöneticilerine yönelik bir ölçek uygulaması yapılmıştır. okullarda yaratıcı drama uygulamalarının yapılması, yaratıcı drama uygulamalarının sonuçlandırılması ve değerlendirilmesi ile ilgili olarak özel ve devlete bağlı ilköğretim okullarındaki okul yönteicilerine yönelik bir ölçek çalışması yapılmıştır.

\section{Yöntem}

\section{Evren ve Örneklem}

Araştırmanın evrenini, 2010-2011 eğitim öğretim yılında İstanbul ili sınırları içinde bulunan Milli Eğitim Bakanlığı'na bağlı resmi ve özel ilköğretim okullarında görev yapmakta olan okul yöneticileri oluşturmaktadır. Araştırmanın örneklemini İstanbul ilinde bulunan Milli Eğitim Bakanlığı'na bağlı resmi ve özel ilköğretim 
okullarından yansız (random) küme örnekleme yöntemi ile seçilen 114 ilköğretim okulunda görev yapan 300 yönetici (müdür ve müdür yardımcıları) oluşturmaktadır. Araştırmaya katılan yöneticilerin \% 16,7'si kadın, \% 83,3' ü erkektir; \% 87,7'si lisans eğitimi \%12,3'ü lisansüstü eğitim almıştır; öte yandan \%84,3'ü yaratıcı drama ile ilgili hizmet içi eğitim almadığını ifade etmiştir.

\section{Veri Toplama Araci}

$\mathrm{Bu}$ araştırmada veriler, araştırmanın bağımlı değişkeni olan eğitim yöneticilerin tutumları "Eğitimde Yaratıcı Drama Etkinliklerine Yönelik Tutum Ölçeği (YDT)" ve bağımsız değişkenleri oluşturan demografik bilgiler "Bireyi Tanıma Formu" kullanılarak toplanmıştır.

\section{Bireyi Tanıma Formu (BTF)}

Bireyi tanıma formu, araştırmacı tarafından yöneticilerin bazı demografik bilgilerini elde etmek için hazırlanmıştır. Okulun toplam mevcudu, okul kaç yıldır faaliyette, yaş, kıdem, eğitim düzeyi, cinsiyet, branş, yaratıcı drama konusunda hizmet içi eğitim alıp almama durumlarına yönelik sorular içermektedir.

\section{Bulgular}

\section{Faktör Analizleri}

Faktör analizi, yorumlanması oldukça güç olan birçok ilişkiyi açıklayan, birbirleriyle korelasyonu olan maddeleri yapısal olarak anlamlı, nispeten bağımsız faktörler altında toplayan çok değişkenli bir analiz tekniğidir. Faktör analizi çok sayıda değişkenden (maddeden) bu değişkenlerin birlikte açılayabildikleri az sayıda tanımlanabilen anlamlı yapılara (faktörlere) ulaşmayı amaçlar (Büyüköztürk, 2002). Faktör analizi aynı zamanda bir yapı geçerliği (construct validity) analizi olarak da tanımlanmaktadır (Köymen, 1994). Ölçeğin faktöryel yapısının belirlenmesi için açımlayıcı (explatory) faktör analizi kullanılmıştır. Açımlayıcı faktör analizinde birbirleriyle ilişkili p tane değişkeni bir araya getirerek değişkenler arasındaki ilişkilerden hareketle az sayıda ve kavramsal olarak anlamlı yeni değişkenler (faktörler) bulmak amaçlanmaktadır (Büyüköztürk, 2002) Ölçeğin faktör yapısını belirlemeye yönelik olarak öncelikle döndürülmemiş temel bileşenler analizi (Principal Component Analysis) uygulanmış, ardından belirlenen faktörleri yorumlamada ve anlamlandırmada kolaylık sağlamak amacıyla Kaiser Normalleştirmesiyle Varimax dik döndürme tekniği (Varimax with Kaiser Normalization) kullanılarak analiz yinelenmiştir. Açımlayıcı faktör analizinin gerçekleştirilebilmesi için öncelikle örneklem büyüklüğünün faktör analizi için uygunluk taşıyıp taşımadığının belirlenmesi gereklidir. Tabachnick ve Fidell (1996) faktör analizinde örneklem büyüklüğü için N=300 kişinin yeterli olduğunu belirtmektedirler.

Bu ölçüt dikkate alınarak Eğitimde Yaratıcı Drama Etkinliklerine Yönelik Tutum Ölçeği (YDT) İstanbul İli’nde görev yapan 300 okul yöneticisine uygulanmıştır. Uygulamaların ardından da örneklem büyüklügünün yeterliğine (sampling adequacy) denetlemek ve faktör analizinin yorumlanabilir olduğuna karar verebilmek için de KMO ve Bartlett Testi sonuçları dikkate alınmıştır. Field (2005) 0 ile 1 arasında değer alabilen KMO değeri; ,50 ile ,70 arasında normal; ,70 ile ,80 arasında iyi, ,80 ile,90 arasında çok iyi ve ,90'ın üzerinde ise mükemmel olarak yorumlanmakta ayrıca Bartlett's Sphericity testinin anlamlı çıkması örneklem büyüklügünün faktör analizi için yeterli/uygun ve korelasyon matrisinin uygun olduğu şeklinde yorumlanmaktadır. Büyüköztürk (2004)'e göre de verilerin faktör analizine uygunluğu için Kaiser-Meyer-Olkin (KMO) .60'dan yüksek ve Barlett Testi'nin istatistiksel olarak anlamlı çıkması gerekmektedir. 
Tablo 1. Kaiser-Meyer-Olkin (KMO) ve Bartlett’s Testi Dĕgerleri (I)

Kaiser-Meyer-Olkin Örneklem Yeterliliği

Ki-kare Değeri

S.Derecesi

$\mathrm{P}$
,941

6499,140

666

, 000

Tabloda görüldüğü üzere KMO değeri $\mathrm{KMO}=, 941$ olarak Bartlett's değeri de anlamlı $(\mathrm{p}<, 001)$ olarak hesaplanmıştır. Bu değerler örneklem büyüklüğünün faktör analizi için uygun olduğunu ve oluşan faktöryel yapının açıklanabilir olduğunu göstermektedir.

Tablo 2. Faktör Analizi (I) Sonuçları

\begin{tabular}{|c|c|c|c|c|c|c|c|c|c|}
\hline \multirow{2}{*}{ Faktörler } & \multicolumn{3}{|c|}{$\begin{array}{c}\text { Başlangıç Özdeğerleri (Initial } \\
\text { Eigenvalues) }\end{array}$} & \multicolumn{3}{|c|}{ Toplam Faktör Yükleri } & \multicolumn{3}{|c|}{$\begin{array}{c}\text { Faktör Yüklerinin Döndürülmüş } \\
\text { Toplamları }\end{array}$} \\
\hline & Toplam & $\begin{array}{l}\text { Açıklanan } \\
\text { Varyans } \%\end{array}$ & Kümülatif \% & Toplam & $\begin{array}{l}\text { Açıklanan } \\
\text { Varyans\% }\end{array}$ & $\underset{\%}{\text { Kümülatif }}$ & Toplam & $\begin{array}{l}\text { Açıklanan } \\
\text { Varyans\% }\end{array}$ & $\underset{\%}{\text { Kümülatif }}$ \\
\hline 1 & 13,74 & 40,42 & 40,42 & 13,74 & 40,42 & 40,42 & 12,76 & 37,54 & 37,54 \\
\hline 2 & 2,90 & 8,53 & 48,94 & 2,90 & 8,53 & 48,94 & 3,03 & 8,91 & 46,45 \\
\hline 3 & 1,33 & 3,90 & 52,84 & 1,33 & 3,90 & 52,84 & 1,72 & 5,07 & 51,51 \\
\hline 4 & 1,28 & 3,78 & 56,61 & 1,28 & 3,78 & 56,61 & 1,32 & 3,89 & 55,40 \\
\hline 5 & 1,03 & 3,04 & 59,65 & 1,03 & 3,04 & 59,65 & 1,32 & 3,87 & 59,27 \\
\hline 6 & 1,02 & 3,00 & 62,64 & 1,02 & 3,00 & 62,64 & 1,15 & 3,37 & 62,64 \\
\hline 7 & 1,00 & 2,93 & 65,58 & . & . & . & . & . & . \\
\hline 8 & ,92 & 2,48 & 65,68 & & & & & & \\
\hline 9 & 85 & 2,30 & 67,98 & & & & & & \\
\hline 10 & ,82 & 2,20 & 70,18 & & & & & & \\
\hline--- & --- & --- & --- & & & & & & \\
\hline 34 &, 140 & ,412 & 100,00 & & & & & & \\
\hline
\end{tabular}




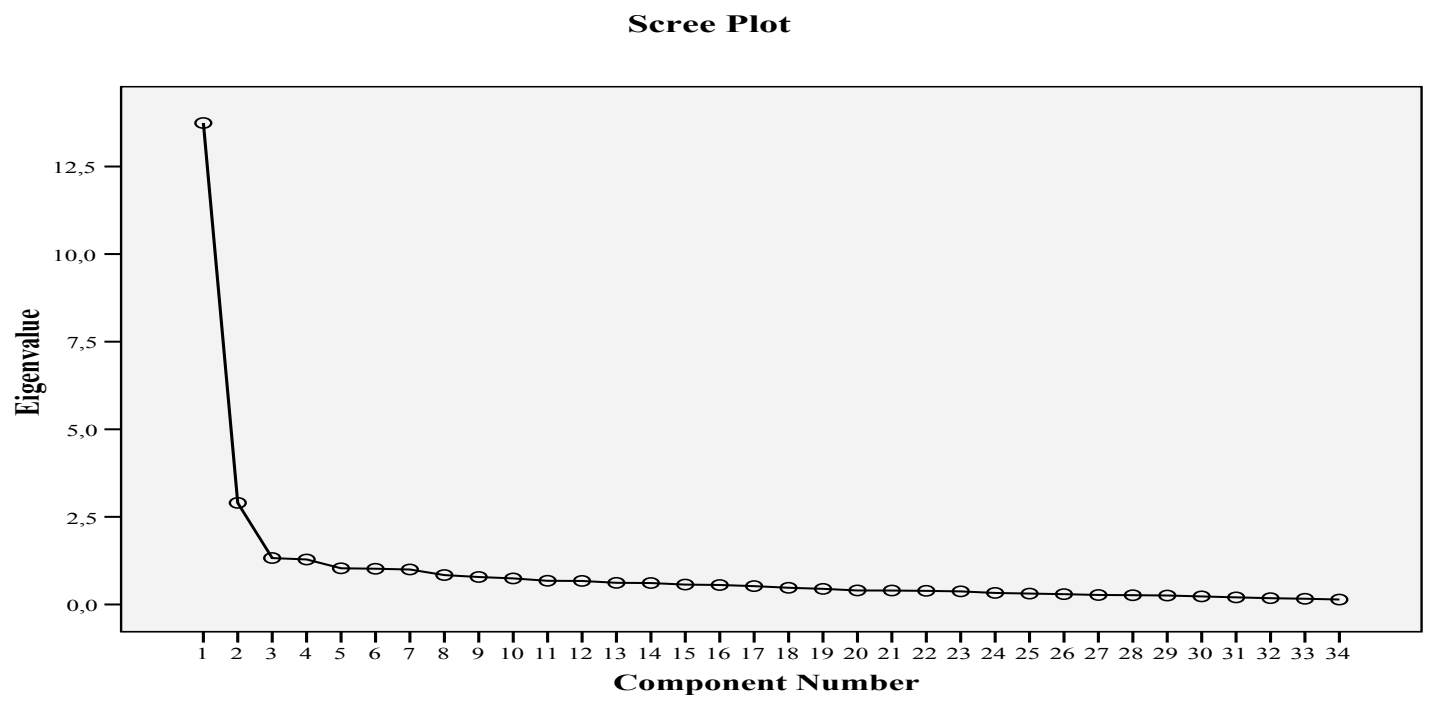

Faktör analizine 34 madde ile ve 1 eigen değeri ile başlanmıştır. Tabloda ve plot tablosunda görüleceği üzere sonuçlar incelendiğinde ölçeğin öz değeri 1'den büyük 6 faktörde toplandığı görülmektedir. Oluşan altı faktörün açıklanan toplam varyans miktarı \% 62,64'tür. Faktörlerin açıkladıkları varyans miktarları \% 40,42 ila \% 2,93 arasında değiştiği belirlenmiştir. Bu sonuçların ardından her bir maddenin diğer madde ve faktörlerle bağlantısını belirlemek için Varimax Dik Döndürme Tekniği kullanılmış ve elde edilen sonuçlar aşağıda sunulmuştur.

Tablo 3. Faktör Analizi (III) Sonrası Dönüştürülmüş Bileşenler Matriksi

\begin{tabular}{|c|c|c|c|c|c|c|}
\hline \multirow{2}{*}{ Maddeler } & \multicolumn{6}{|c|}{ Component } \\
\hline & 1 & 2 & 3 & 4 & 5 & 6 \\
\hline $\begin{array}{l}\text { 23. Eğitimde yaratıcı dramanın bireyin kendini daha iyi } \\
\text { tanımasını sağladığını düşünüyorum. }\end{array}$ & ,829 & & & & & \\
\hline $\begin{array}{l}\text { 31. Zor öğrenciler için planlanan eğitim programında eğitimde } \\
\text { yaratıcı drama çalışmalarına yer verilmesini öneririm. }\end{array}$ & 812 & & & & & \\
\hline $\begin{array}{l}\text { 16. Eğitimde yaratıcı dramanın çocuk eğitimine katkısı çok } \\
\text { fazladır. }\end{array}$ & ,802 & & & & & \\
\hline $\begin{array}{l}\text { 17. Eğitimde yaratıcı dramanın, öğrencilerin ilişkilerinde } \\
\text { empatiyi etkin olarak kullanmalarını sağladığını } \\
\text { düşünüyorum. }\end{array}$ & ,784 & & & & & \\
\hline $\begin{array}{l}\text { 30. Okul kütüphanesindeki eğitimde yaratıcı drama } \\
\text { yayınlarının sayısının artması gerekir. }\end{array}$ & ,778 & & & & & \\
\hline $\begin{array}{l}\text { 32. Öğrencilerin eğitimde yaratıcı drama etkinliklerine ilgisini } \\
\text { arttırıcı çalıșmalar yapılmasını desteklerim. }\end{array}$ & ,774 & & & & & \\
\hline
\end{tabular}


22. Eğitimde yaratıcı dramanın öğrencilerin ifade edemediği sorunlarını ortaya çıkaran bir araç olduğunu düşünüyorum.

33. Öğrenciler arasındaki sorunların çözümünde eğitimde yaratıcı drama etkinliklerinden yararlanılmasını teşvik ederim.

6. Eğitimde yaratıcı dramanın sosyalleşme sürecinde öğrencilere yardımcı olduğunu düşünüyorum.

18. Eğitimde yaratıcı dramanın bireydeki farkındalı̆ğ arttırdığını düşünüyorum.

13. Eğitimde yaratıcı drama çocuğun lehine sonuçlar doğurur.

5. Eğitimde yaratıcı dramanın kendini gerçekleştirme sürecinin bir aşaması olduğu düşüncesindeyim.

9. Eğitimde yaratıcı dramanın bireyin duygularını daha iyi tanımasını sağladığını düşünüyorum.

14. Öğrenciler arasındaki problemlerin çözümünde eğitimde yaratıcı dramanın yöntem olarak kullanılabileceği kanaatindeyim.

24. Okulda eğitimde yaratıcı drama sosyal çatışmaları çözmede prova işlevi üstlenebilir.

20. Eğitimde yaratıcı drama öğrencilerin daha sağlıklı bir bireyler olmalarına yardımcı olur.

21. Eğitimde yaratıcı dramanın, okulda zorbalık eğilimlerini azaltacağını düşünüyorum.

27. Okulda, eğitimde yaratıcı dramayı, seçmeli ders olarak okutulması için öneririm.

7. Eğitimde yaratıcı dramanın içerik ve amaçlarını ilgililere anlatacak birikime sahip olmak isterim.

28. Dersinde, eğitimde yaratıcı drama uygulayan öğretmeni desteklerim.

15. Öğrenci tanıma çalışmalarında rehber öğretmenlerin eğitimde yaratıcı drama etkinliklerinden yararlanmasını teşvik ederim. 
8. Okulda, eğitimde yaratıcı dramaya izin vererek öğrencinin demokrasi bilincini benimsemesine katkı sağlarım.

3. Öğretmenleri eğitimde yaratıcı drama ile ilgili hizmet içi eğitim almaya yönlendiririm.

10. Eğitimde yaratıcı dramanın insani değerlerin gelişmesine katkısı olduğunu düşünmüyorum.

4. Eğitimde yaratıcı dramanın bireyin sosyal ilişkilerini zenginleştirebileceğini düşünmüyorum.

25. Eğitimde yaratıcı drama etkinliklerinin okuldaki disiplin sorunlarının azalmasında etkili olacağını düşünmüyorum.

11. Eğitimde yaratıcı dramanın amaçlarının sınıflarda gerçekleşeceğini düşünmüyorum.

2. Kimlik gelişiminde,eğitimde yaratıcı dramanın önemli olduğunu düşünmüyorum.

26. Eğitimde yaratıcı dramanın sadece çocuklara yönelik olabileceğini düşünüyorum.

19. Eğitimde yaratıcı drama gösteriden başka bir şey değil.

1. Eğitimde yaratıcı drama ile ilgili yayınları okurum.

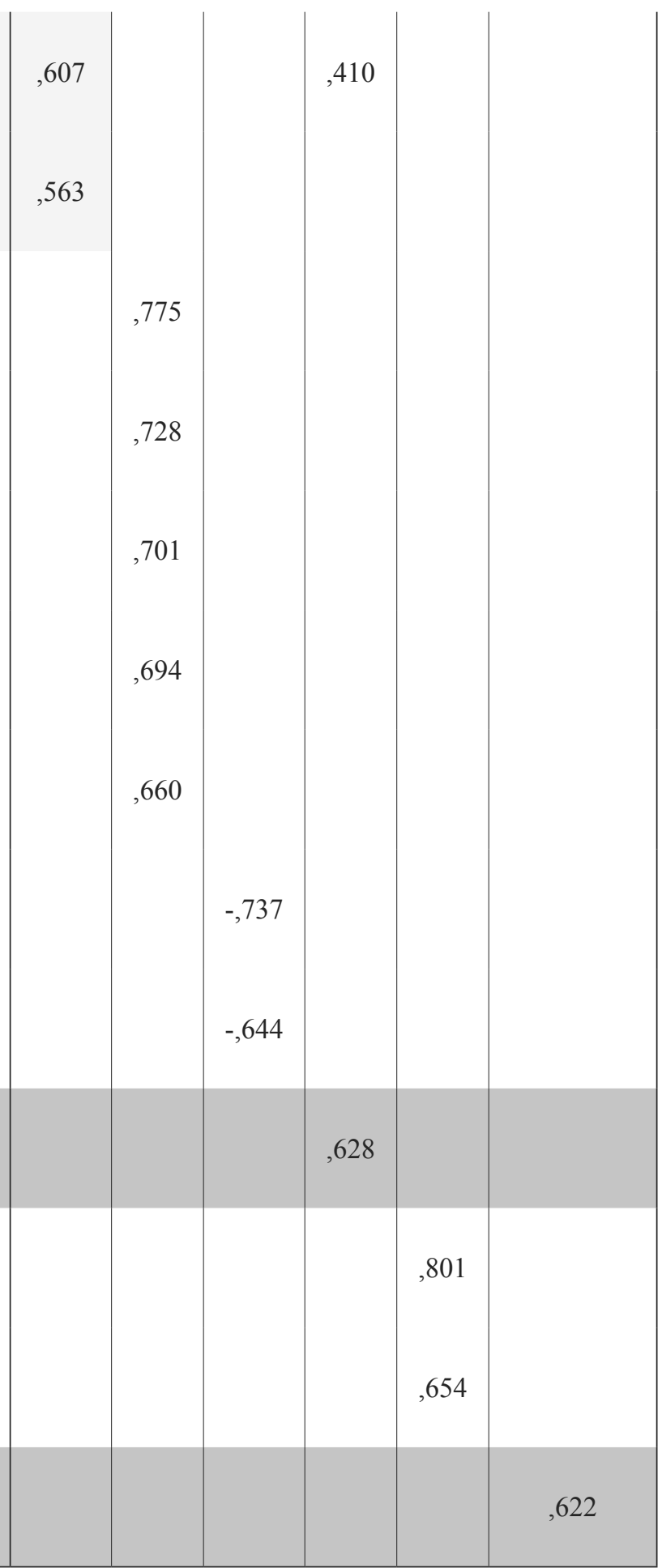

29. Eğitimde yaratıcı drama etkinlikleri sanatsal gelişime katk1 sağlar.

12. Eğitimde yaratıcı dramanın ayrı bir uzmanlık alanı olmasina gerek yok.

34. Eğitimde yaratıcı dramaya ayrı bir ders olarak okul programında yer vermem olanaklı değildir.

Tabloda görüldüğü üzere 4.ve 6. faktör tek mddeden oluşmaktadır. Bu nedenle söz konusu maddeler elenerek faktör analizi işlemleri tekrarlanmıştır. 
Tablo 4. Kaiser-Meyer-Olkin (KMO) ve Bartlett's Testi Değerleri (II)

Kaiser-Meyer-Olkin Örneklem Yeterliliği

,947

Ki-kare Değeri

5999,345

Bartlett's Test of Sphericity

S.Derecesi

496

$\mathrm{P}$

, 000

Tabloda görüldüğü üzere $\mathrm{KMO}$ değeri $\mathrm{KMO}=, 947$ olarak Bartlett's değeri de anlamlı $(\mathrm{p}<, 001)$ olarak hesaplanmıştır. Bu değerler örneklem büyüklüğünün faktör analizi için uygun olduğunu ve oluşan faktöryel yapının açıklanabilir olduğunu göstermektedir.

Tablo 5. Faktör Analizi (II) Sonuçları

\begin{tabular}{|c|c|c|c|c|c|c|c|c|c|}
\hline \multirow{2}{*}{ Faktörler } & \multicolumn{3}{|c|}{$\begin{array}{l}\text { Başlangıç Özdeğerleri } \\
\text { (Initial Eigenvalues) }\end{array}$} & \multicolumn{3}{|c|}{ Toplam Faktör Yükleri } & \multicolumn{3}{|c|}{$\begin{array}{c}\text { Faktör Yüklerinin Döndürülmüş } \\
\text { Toplamları }\end{array}$} \\
\hline & Toplam & $\begin{array}{l}\text { Açıklanan } \\
\text { Varyans\% }\end{array}$ & $\begin{array}{c}\text { Kümülatif } \\
\%\end{array}$ & Toplam & $\begin{array}{l}\text { Açıklanan } \\
\text { Varyans\% }\end{array}$ & $\begin{array}{c}\text { Kümülatif } \\
\%\end{array}$ & Toplam & $\begin{array}{l}\text { Açıklanan } \\
\text { Varyans\% }\end{array}$ & $\begin{array}{c}\text { Kümülatif } \\
\%\end{array}$ \\
\hline 1 & 13,55 & 42,33 & 42,33 & 13,55 & 42,33 & 42,33 & 12,79 & 39,96 & 39,96 \\
\hline 2 & 2,81 & 8,79 & 51,12 & 2,81 & 8,79 & 51,12 & 2,96 & 9,24 & 49,20 \\
\hline 3 & 1,32 & 4,12 & 55,24 & 1,32 & 4,12 & 55,24 & 1,71 & 5,33 & 54,53 \\
\hline 4 & 1,21 & 3,78 & 59,03 & 1,21 & 3,78 & 59,03 & 1,31 & 4,09 & 58,62 \\
\hline 5 & 1,02 & 3,18 & 62,21 & 1,02 & 3,18 & 62,21 & 1,15 & 3,59 & 62,21 \\
\hline 6 & ,90 & 2,82 & 65,03 & . & . & . & . & . & . \\
\hline 7 &, 83 & 2,61 & 67,63 & . & . & . & . & . & . \\
\hline 8 & ,76 & 2,36 & 69,99 & . & . & . & . & . & . \\
\hline 9 & ,73 & 2,28 & 72,27 & . & . & . & . & . & . \\
\hline 10 & ,68 & 2,13 & 74,41 & . & . & . & . & . & . \\
\hline --- & . & . & . & . & . & . & . & . & . \\
\hline 32 &, 14 & ,44 & 100,00 & . & . & . & . & . & . \\
\hline
\end{tabular}




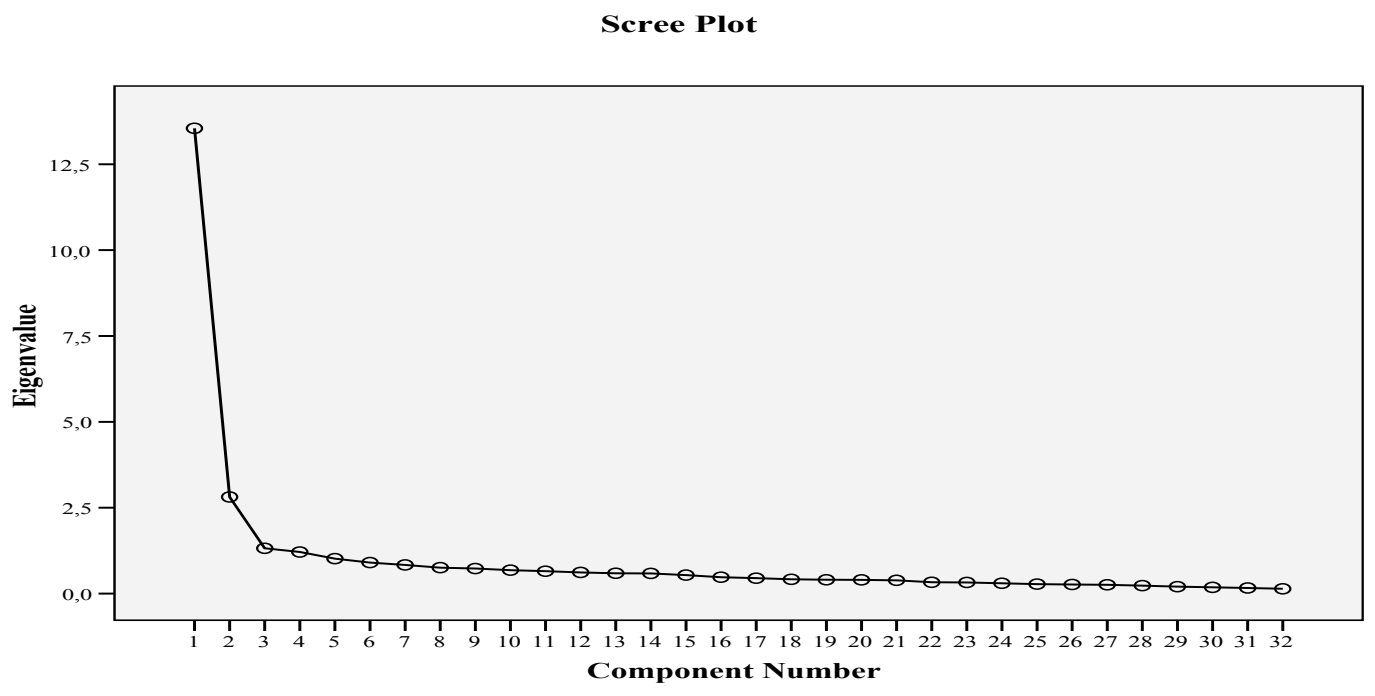

İkinci basamak faktör analizine 32 madde ile ve 1 eigen değeri ile başlanmıştır. Tabloda ve plot tablosunda görüleceği üzere sonuçlar incelendiğinde ölçeğin öz değeri 1'den büyük 5 faktörde toplandığ görülmektedir. Oluşan altı faktörün açıklanan toplam varyans miktarı \% 62,21'dir. Faktörlerin açıkladıkları varyans miktarları \% 42,33 ila \% 2,13 arasında değiştiği belirlenmiştir. Bu sonuçların ardından her bir maddenin diğer madde ve faktörlerle bağlantısını belirlemek için Varimax Dik Döndürme Tekniği kullanılmış ve elde edilen sonuçlar aşağıda sunulmuştur.

Tablo 6. Faktör Analizi (II) Sonrası Dönüştürülmüş Bileşenler Matriksi

\begin{tabular}{|c|c|c|c|c|c|}
\hline \multirow{2}{*}{ Maddeler } & \multicolumn{5}{|c|}{ Component } \\
\hline & 1 & 2 & 3 & 4 & 5 \\
\hline $\begin{array}{l}\text { 32. Öğrencilerin eğitimde yaratıcı drama etkinliklerine ilgisini arttırıcı } \\
\text { çalışmalar yapılmasını desteklerim. }\end{array}$ & ,809 & & & & \\
\hline 16. Eğitimde yaratıcı dramanın çocuk eğitimine katkısı çok fazladır. & ,807 & & & & \\
\hline $\begin{array}{l}\text { 33. Öğrenciler arasındaki sorunların çözümünde eğitimde yaratıcı drama } \\
\text { etkinliklerinden yararlanılmasını teşvik ederim. }\end{array}$ & ,804 & & & & \\
\hline $\begin{array}{l}\text { 23. Eğitimde yaratıcı dramanın bireyin kendini daha iyi tanımasını sağladığını } \\
\text { düşünüyorum. }\end{array}$ & ,803 & & & & \\
\hline $\begin{array}{l}\text { 9. Eğitimde yaratıcı dramanın bireyin duygularını daha iyi tanımasını } \\
\text { sağladığını düşünüyorum. }\end{array}$ & ,789 & & ,308 & & \\
\hline
\end{tabular}


30. Okul kütüphanesindeki eğitimde yaratıcı drama yayınlarının sayısının artması gerekir.

31. Zor öğrenciler için planlanan eğitim programında eğitimde yaratıcı drama çalışmalarına yer verilmesini öneririm.

6. Eğitimde yaratıcı dramanın sosyalleşme sürecinde öğrencilere yardımcı olduğunu düşünüyorum.

17. Eğitimde yaratıcı dramanın, öğrencilerin iliş̧kilerinde empatiyi etkin olarak kullanmalarını sağladığını düşünüyorum.

5. Eğitimde yaratıcı dramanın kendini gerçekleştirme sürecinin bir aşaması olduğu düşüncesindeyim.

14. Öğrenciler arasındaki problemlerin çözümünde eğitimde yaratıcı dramanın yöntem olarak kullanılabileceği kanaatindeyim.

13. Eğitimde yaratıcı drama çocuğun lehine sonuçlar doğurur.

18. Eğitimde yaratıcı dramanın bireydeki farkındalığı arttırdığını düşünüyorum.

7. Eğitimde yaratıcı dramanın içerik ve amaçlarını ilgililere anlatacak birikime sahip olmak isterim.

22. Eğitimde yaratıcı dramanın öğrencilerin ifade edemediği sorunlarını ortaya çıkaran bir araç olduğunu düşünüyorum.

24. Okulda eğitimde yaratıcı drama sosyal çatışmaları çözmede prova işlevi üstlenebilir.

28. Dersinde, eğitimde yaratıcı drama uygulayan öğretmeni desteklerim.

20. Eğitimde yaratıcı drama öğrencilerin daha sağlıklı bir bireyler olmalarına yardımci olur.

15. Öğrenci tanıma çalışmalarında rehber öğretmenlerin eğitimde yaratıcı drama etkinliklerinden yararlanmasını teşvik ederim.

21. Eğitimde yaratıcı dramanın, okulda zorbalık eğilimlerini azaltacağını düşünüyorum. 
8. Okulda, eğitimde yaratıcı dramaya izin vererek öğrencinin demokrasi bilincini benimsemesine katkı sağlarım.

27. Okulda, eğitimde yaratıcı dramayı, seçmeli ders olarak okutulması için öneririm.

3. Öğretmenleri eğitimde yaratıcı drama ile ilgili hizmet içi eğitim almaya yönlendiririm.

10. Eğitimde yaratıcı dramanın insani değerlerin gelişmesine katkısı olduğunu düşünmüyorum.

4. Eğitimde yaratıcı dramanın bireyin sosyal ilişkilerini zenginleştirebileceğini düşünmüyorum.

2. Kimlik gelişiminde, eğitimde yaratıcı dramanın önemli olduğunu düşünmüyorum.

25. Eğitimde yaratıcı drama etkinliklerinin okuldaki disiplin sorunlarının azalmasında etkili olacağını düşünmüyorum.

11. Eğitimde yaratıcı dramanın amaçlarının sınıflarda gerçekleşeceğini düşünmüyorum.

26. Eğitimde yaratıcı dramanın sadece çocuklara yönelik olabileceğini düşünüyorum.

19. Eğitimde yaratıcı drama gösteriden başka bir şey değil.

12. Eğitimde yaratıcı dramanın ayrı bir uzmanlık alanı olmasına gerek yok.

29. Eğitimde yaratıcı drama etkinlikleri sanatsal gelişime katkı sağlar.

Tabloda görüldüğü üzere 4.ve 5. faktör tek mddeden oluşmaktadır. Bu nedenle söz konusu maddeler elenerek faktör analizi işlemleri tekrarlanmıştır. 
Tablo 7. Kaiser-Meyer-Olkin (KMO) ve Bartlett’s Testi Değerleri (III)

Kaiser-Meyer-Olkin Örneklem Yeterliliği

,951

Ki-kare Değeri

5906,072

Bartlett's Test of Sphericity

S.Derecesi

435

$\mathrm{p}$

, 000

Tabloda görüldüğg̈ üzere $\mathrm{KMO}$ değeri $\mathrm{KMO}=, 947$ olarak Bartlett's değeri de anlamlı $(\mathrm{p}<, 001)$ olarak hesaplanmıştır. Bu değerler örneklem büyüklüğünün faktör analizi için uygun olduğunu ve oluşan faktöryel yapının açıklanabilir olduğunu göstermektedir.

Tablo 8. Faktör Analizi (III) Sonuçları

\begin{tabular}{|c|c|c|c|c|c|c|c|c|c|}
\hline \multirow{2}{*}{ Faktörler } & \multicolumn{3}{|c|}{$\begin{array}{l}\text { Başlangıç Özdeğerleri } \\
\text { (Initial Eigenvalues) }\end{array}$} & \multicolumn{3}{|c|}{ Toplam Faktör Yükleri } & \multicolumn{3}{|c|}{$\begin{array}{c}\text { Faktör Yüklerinin Döndürülmüş } \\
\text { Toplamları }\end{array}$} \\
\hline & Toplam & $\begin{array}{l}\text { Açıklanan } \\
\text { Varyans\% }\end{array}$ & $\begin{array}{l}\text { Kümülatif } \\
\%\end{array}$ & Toplam & $\begin{array}{l}\text { Açıklanan } \\
\text { Varyans\% }\end{array}$ & $\begin{array}{l}\text { Kümülatif } \\
\%\end{array}$ & Toplam & $\begin{array}{l}\text { Açıklanan } \\
\text { Varyans\% }\end{array}$ & $\begin{array}{c}\text { Kümülatif } \\
\%\end{array}$ \\
\hline 1 & 13,53 & 45,11 & 45,11 & 13,53 & 45,11 & 45,11 & 7,76 & 25,86 & 25,86 \\
\hline 2 & 2,76 & 9,19 & 54,30 & 2,76 & 9,19 & 54,30 & 6,09 & 20,29 & 46,15 \\
\hline 3 & 1,21 & 4,04 & 58,34 & 1,21 & 4,04 & 58,34 & 2,92 & 9,72 & 55,87 \\
\hline 4 & 1,03 & 3,43 & 61,77 & 1,03 & 3,43 & 61,77 & 1,77 & 5,90 & 61,77 \\
\hline 5 & ,88 & 2,94 & 64,71 & & & & & & \\
\hline 6 &, 78 & 2,59 & 67,30 & & & & & & \\
\hline 7 & ,76 & 2,53 & 69,83 & & & & & & \\
\hline 8 &, 70 & 2,32 & 72,15 & & & & & & \\
\hline 9 & ,66 & 2,21 & 74,36 & & & & & & \\
\hline 10 & ,62 & 2,07 & 76,43 & & & & & & \\
\hline--- & . & . & . & & & & & & \\
\hline 30 &, 14 & ,47 & 100,00 & . & . & . & . & . & . \\
\hline
\end{tabular}




\section{Scree Plot}

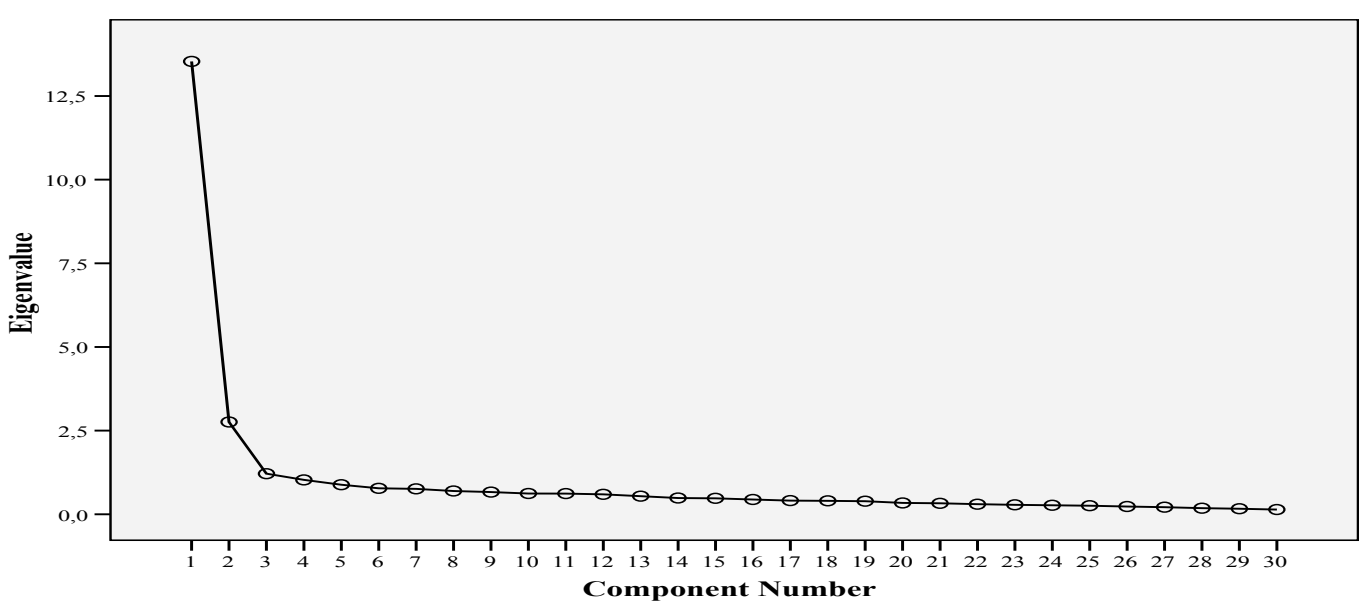

İkinci basamak faktör analizine 30 madde ile ve 1 eigen değeri ile başlanmıştır. Tabloda ve plot tablosunda görüleceği üzere sonuçlar incelendiğinde ölçeğin öz değeri 1'den büyük 4 faktörde toplandığı görülmektedir. Oluşan altı faktörün açıklanan toplam varyans miktarı \% 61,77'dir. Faktörlerin açıkladıkları varyans miktarları $\% 45,11$ ila \% 3,43 arasında değiştiği belirlenmiştir. Bu sonuçların ardından her bir maddenin diğer madde ve faktörlerle bağlantısını belirlemek için Varimax Dik Döndürme Tekniği kullanılmış ve elde edilen sonuçlar aşağıda sunulmuştur.

Tablo 9. Faktör Analizi (III) Sonrası Dönüştürülmüş Bileşenler Matriksi

\begin{tabular}{|c|c|c|c|c|}
\hline \multirow{2}{*}{ Maddeler } & \multicolumn{4}{|c|}{ Component } \\
\hline & 1 & 2 & 3 & 4 \\
\hline $\begin{array}{l}\text { 32. Öğrencilerin eğitimde yaratıcı drama etkinliklerine ilgisini artırııı çalışmalar } \\
\text { yapılmasını desteklerim. }\end{array}$ &, 770 & & & \\
\hline $\begin{array}{l}\text { 9. Eğitimde yaratıcı dramanın bireyin duygularını daha iyi tanımasını sağladığını } \\
\text { düşünüyorum. }\end{array}$ & ,752 & & & \\
\hline $\begin{array}{l}\text { 8. Okulda, eğitimde yaratıcı dramaya izin vererek öğrencinin demokrasi bilincini } \\
\text { benimsemesine katkı sağlarım. }\end{array}$ &, 741 & & & \\
\hline $\begin{array}{l}\text { 33. Öğrenciler arasındaki sorunların çözümünde eğitimde yaratıcı drama } \\
\text { etkinliklerinden yararlanılmasını teşvik ederim. }\end{array}$ & ,726 & & & \\
\hline $\begin{array}{l}\text { 14. Öğrenciler arasındaki problemlerin çözümünde eğitimde yaratıcı dramanın } \\
\text { yöntem olarak kullanılabileceği kanaatindeyim. }\end{array}$ &, 721 & & & \\
\hline $\begin{array}{l}\text { 7. Eğitimde yaratıcı dramanın içerik ve amaçlarını ilgililere anlatacak birikime } \\
\text { sahip olmak isterim. }\end{array}$ & ,678 & & & \\
\hline
\end{tabular}


6. Eğitimde yaratıcı dramanın sosyalleşme sürecinde öğrencilere yardımcı olduğunu düşünüyorum.

13. Eğitimde yaratıcı drama çocuğun lehine sonuçlar doğurur.

30. Okul kütüphanesindeki eğitimde yaratıcı drama yayınlarının sayısının artması gerekir.

16. Eğitimde yaratıcı dramanın çocuk eğitimine katkısı çok fazladır.

5. Eğitimde yaratıcı dramanın kendini gerçekleştirme sürecinin bir aşaması olduğu düşüncesindeyim.

15. Öğrenci tanıma çalışmalarında rehber öğretmenlerin eğitimde yaratıcı drama etkinliklerinden yararlanmasını teşvik ederim.

28. Dersinde, eğitimde yaratıı drama uygulayan öğretmeni desteklerim.

3. Öğretmenleri eğitimde yaratıcı drama ile ilgili hizmet içi eğitim almaya yönlendiririm.

22. Eğitimde yaratıcı dramanın öğrencilerin ifade edemediği sorunlarını ortaya çıkaran bir araç olduğunu düşünüyorum.

23. Eğitimde yaratıcı dramanın bireyin kendini daha iyi tanımasını sağladığını düşünüyorum.

24. Okulda eğitimde yaratıcı drama sosyal çatışmaları çözmede prova işlevi üstlenebilir.

21. Eğitimde yaratıcı dramanın, okulda zorbalık eğilimlerini azaltacağını düşünüyorum.

27. Okulda , eğitimde yaratıcı dramayı, seçmeli ders olarak okutulması için öneririm.

20. Eğitimde yaratıcı drama öğrencilerin daha sağlıklı bir bireyler olmalarına yardımcı olur.

18. Eğitimde yaratıcı dramanın bireydeki farkındalığı arttırdığını düşünüyorum. 
31. Zor öğrenciler için planlanan eğitim programında eğitimde yaratıcı drama çalışmalarına yer verilmesini öneririm.

17. Eğitimde yaratıcı dramanın, öğrencilerin ilişkilerinde empatiyi etkin olarak kullanmalarını sağladığını düşünüyorum.

10. Eğitimde yaratıcı dramanın insani değerlerin gelişmesine katkısı olduğunu düşünmüyorum.

4. Eğitimde yaratıcı dramanın bireyin sosyal ilişkilerini zenginleştirebileceğini düşünmüyorum.

25. Eğitimde yaratıcı drama etkinliklerinin okuldaki disiplin sorunlarının azalmasında etkili olacağını düşünmüyorum.

2. Kimlik gelişiminde,eğitimde yaratıcı dramanın önemli olduğunu düşünmüyorum.

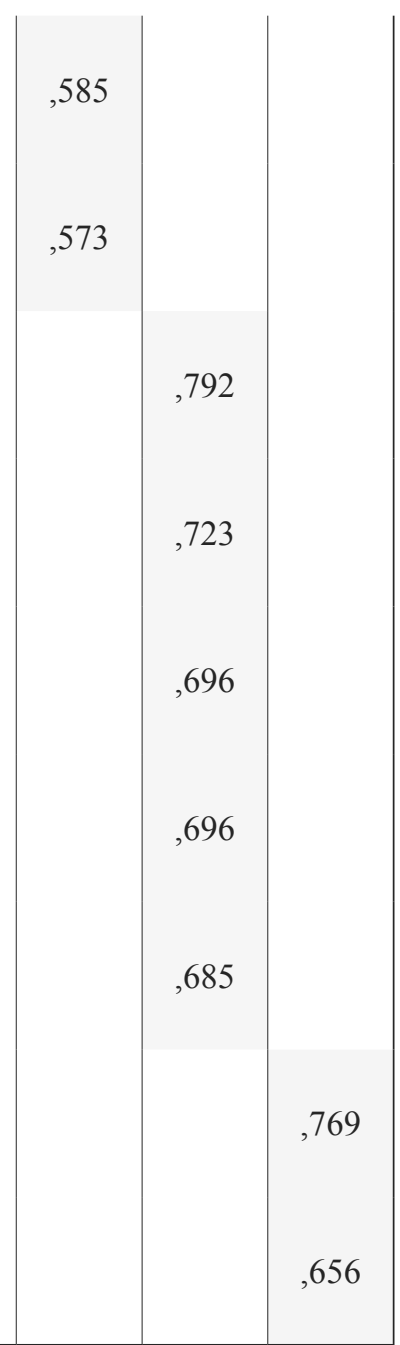

11. Eğitimde yaratıcı dramanın amaçlarının sınıflarda gerçekleşeceğini düşünmüyorum.

26. Eğitimde yaratıcı dramanın sadece çocuklara yönelik olabileceğini düşünüyorum.

19. Eğitimde yaratıcı drama gösteriden başka bir şey değil.

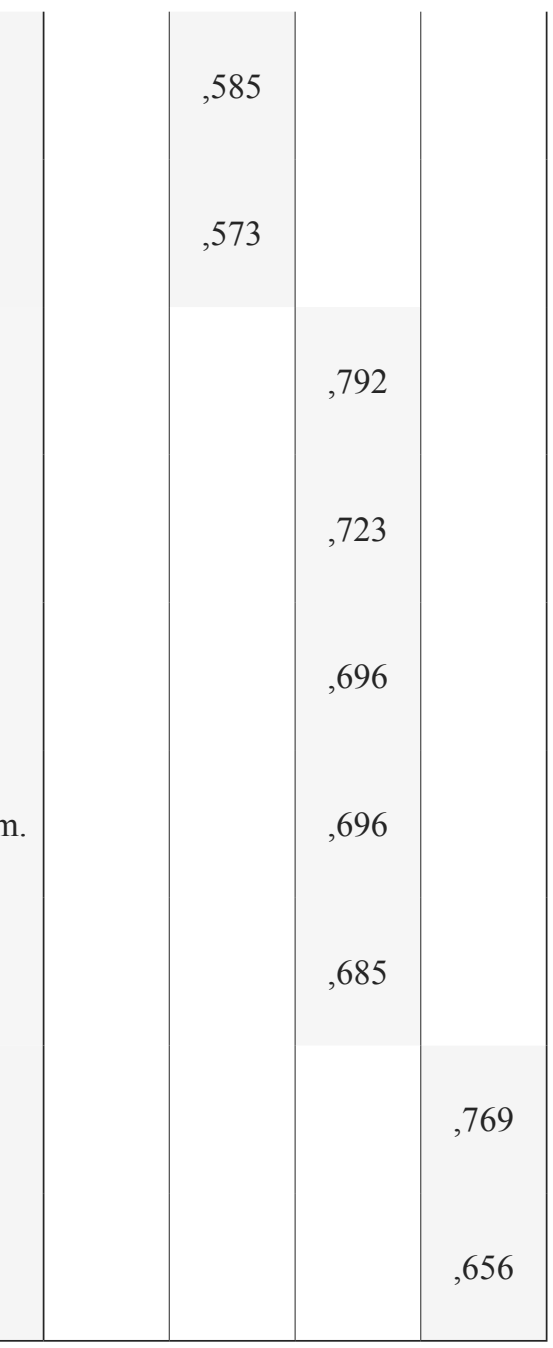

Varimax Dik Döndürme işleminden elde edilen, her bir maddenin faktörlerden aldıkları yüklere ait değerler tabloda sunulmuştur. Maddelerin içerisinde 0,30'dan daha düşük yük alan madde bulunmamaktadır. $\mathrm{Bu}$ nedenle faktör analizi sonlandırılmıştır. Oluşan faktörlere ait maddeler ve madde sayıları aşağıdaki tabloda sunulmuştur.

Tablo 10. Faktör Analizi Sonucunda Belirlenen Alt Boyutlar ve Bu Boyutlardan Yük Alan Maddeler

\begin{tabular}{ccc}
\hline Faktörler & $\begin{array}{c}\text { Madde } \\
\text { Sayıs }\end{array}$ & Maddeler \\
\hline Faktör 1 (Kişisel Gelişimi Destekleyicilik) & 14 madde & $3,4,6,7,8,9,13,14,16,18,28,30,32,33$ \\
Faktör 2 (İletişim ve uyumu Destekleyicilik) & 9 madde & $17,18,20,21,22,23,24,27,31$ \\
Faktör 3 (İşlevsizlik) & 5 madde & $2,4,10,11,25$ \\
Faktör 4 (Sinırlılık) & 2 madde & 19,26 \\
\hline
\end{tabular}


Tabloda da görüldüğü üzere belirlenen birinci faktör 14 maddeden $(3,4,6,7,8,9,13,18,14,16,28$, 30, 32, 33. maddeler); ikinci faktör 9 maddeden (17, 18, 20, 21, 22, 23, 24, 27, 31. maddeler); üçüncü faktör 5 maddeden $(2,4,10,11,25$. maddeler); dördüncü faktör 2 maddeden $(19,26$. maddeler) oluşmaktadır. İçinde yer aldığı faktörde ters madde işlevi gören madde bulunmamaktadır.

Son hâlinde ölçek 30 maddeden oluşmaktadır. Bu sonuçların ardından her bir faktör içine giren maddeler incelenerek oluşan alt boyutlar isimlendirilmiştir. Bu bağlamda birinci alt boyutun eğitimi ve bireyin gelişimini destekleyici anlam taşıyan maddeler içerdiği göz önünde bulundurularak "Gelişimi Destekleyicilik" alt boyutu olarak; ikinci alt boyutun eğitimde yaratıcı dramanın iletişim ve çevreye uyumu destekleyen maddeler içerdiğinden "iletişim ve uyumu destekleyicilik" alt boyutu olarak; üçüncü alt boyutun eğitimde yaratıcı dramanın eğitim sürecinde etkisiz olduğunu ifade eden maddeler içerdiğinden "İşlevsizlik" alt boyutu olarak; dördüncü alt boyutun de eğitimde yaratıcı drama etkinliklerinin belirli bir yaşa hitap ettiği ve oyun etkinliklerini andırdığını ifade eden maddeler içermesi göz önünde bulundurularak "Sınırlılık" alt boyutu olarak isimlendirilmesi uygun görülmüştür. Ayrıca ölçeğin, Eğitimde Yaratıcı Drama Etkinliklerine Yönelik Tutum Ölçeği (YDT) olarak adlandırılmasına karar verilmiştir. Bu işlemlerin ardından da madde analizlerine geçilmiştir.

\section{Madde Analizleri (Item-Total / Item Reminder)}

Maddelerin ölçek toplam puanları ile ilişkilerini belirlemek amacıyla madde toplam (item-total) ve madde kalan (item reminder) analizleri gerçekleştirilmiştir. Kalaycı (2006) bu değerlerin yüksek çıkmasının maddelerin ölçek için önemli olduklarını gösterdiğini belirtmektedir. Maddelerin ölçek toplam puanları (madde toplam / item-total) ile arasındaki ilişkinin belirlenmesi amacıyla yapılan Pearson analizi sonucunda tüm maddelerin toplam puanla arasındaki ilişkilerin en düşük $\mathrm{p}<, 05$ düzeyinde anlamlı olduğu saptanmıştır. Bu sonuçlar tüm maddelerin ölçeğin amacına hizmet ettiğini göstermektedir. Öte yandan 3. ve 4. faktöre giren maddelerin $(2,4$, 10, 11, 19, 25, 26) ölçek toplam puanları ile ilişkisinin negatif olduğu belirlenmiştir. Bu nedenle ölçek toplam puanlarının hesaplanmasında söz konusu maddelerin tersinden puanlanması kararlaştırılmıştır.

Maddelerin ölçek toplam puanları ile (madde kalan /item-reminder) arasındaki ilişkinin belirlenmesi amacıyla yapılan Pearson analizi sonucunda tüm maddelerin toplam puanla arasındaki ilişkilerin en düşük $\mathrm{p}<, 05$ düzeyinde anlamlı olduğu saptanmıştır. Bu sonuçlar tüm maddelerin ölçeğin amacına hizmet ettiğini göstermektedir. Bu sonuçların ardından maddelerin ayırt edicilikleri belirlenmiştir.

\section{Güvenirlik Analizleri (Cronbach's Alpha) İç Tutarlılık Analizi}

Bir ölçme aracının güvenirliğini belirlemenin birçok yolu bulunmaktadır. Likert tipi bir ölçeğin iç tutarlılığını saptamak için sıklıkla Cronbach’s Alpha güvenirlik ölçütünün kullanılmaktadır. Özgüven (1999). Cronbach Alpha güvenirlik katsayısının ölçek içinde bulunan maddelerin homojenliğinin bir ölçüsü olduğunu, Alpha katsayısı ne kadar yüksek olursa, bu ölçekte bulunan maddelerin o ölçüde birbirleriyle tutarlı ve aynı özelliğin öğelerini yordayan maddelerden oluştuğunun varsayılabileceğini belirtmektedir. Öte yandan Tavşancıl (2002) Alpha katsayısının ,70 ve üzerinde olması durumunda ölçme aracının araştırmalarda kullanılabileceğini belirtilmektedir. Büyüköztürk (2008) de ölçeğin güvenirlik katsayısının ,70 ve daha yüksek olmasının ölçeğin güvenirlik açısından yeterli olduğu şeklinde yorumlanabilir.

Ölçeğin iç tutarlık güvenirliğini belirlemek üzere yapılan analizlerin ardından testin tamamı için toplam Cronbach Alpha değeri $\alpha=, 85$ olarak hesaplanmıştır. Ayrıca bu analizler sonucunda ölçekteki tüm maddelerin Alpha değeri üzerinde pozitif etkide bulunduğu, iç tutarlığı artırabilmek için bir madde eleme gerekliliği bulunmadığı sonucuna ulaşılmıştır. Ölçeğin güvenirliğini belirlemek amacıyla yapılan diğer analizlerle birlikte her bir faktör için de yapılan Cronbach’s Alpha sonuçları aşağıda sunulmuştur. 
Tablo 11. Faktör Analizi Sonucunda Belirlenen Alt Boyutlar ve Bu Boyutlardan Ait Güvenirlik Katsayıları

\begin{tabular}{lc}
\hline \multicolumn{1}{c}{ Faktör } & C. Alpha \\
\hline Faktör 1 (Kişisel Gelişimi Destekleyicilik) &, 914 \\
Faktör 2 (İletişim ve uyumu Destekleyicilik) &, 921 \\
Faktör 3 (İşlevsizlik) &, 782 \\
Faktör 4 (Sı̀nırlılık) &, 712 \\
Toplam &, 909 \\
\hline
\end{tabular}

Tablodan da anlaşılacağı gibi Eğitimde Yaratıcı Drama Etkinliklerine Yönelik Tutum Ölçeğinin (YDT) iç tutarlık kat sayıları oldukça yüksek bulunmuştur. Cronbach's Alpha değerleri $\alpha=0,921$ ila $\alpha=0,712$ arasında yer almıştır. Ölçeğin toplamı için de Alpha değeri $\alpha=0,909$ olarak hesaplanmıştır. Ölçek toplamı için elde edilen değerler ölçeğin iç tutarlık açısından oldukça avantajlı olduğunu ispatlamaktadır. Bu işlemlerin ardından faktörler arası korelasyonları hesaplanması işlemlerine geçilmiştir.

Tablo 12. Ölçek Alt boyutları Arasındaki Korelasyonlar

\begin{tabular}{|c|c|c|c|c|c|}
\hline Ölçek Alt Boyutları & & $\begin{array}{c}\text { Faktör } 2 \\
\text { (Iletişim ve uyumu } \\
\text { Destekleyicilik) }\end{array}$ & $\begin{array}{c}\text { Faktör } 3 \\
\text { (İşlevsizlik) }\end{array}$ & $\begin{array}{c}\text { Faktör } 4 \\
\text { (Sinırlılık) }\end{array}$ & Toplam \\
\hline \multirow{3}{*}{$\begin{array}{c}\text { Faktör 1 } \\
\text { (Kişisel Gelişimi } \\
\text { Destekleyicilik) }\end{array}$} & $\mathrm{r}$ &, 870 &,- 334 &,- 435 &, 817 \\
\hline & $\mathrm{p}$ &, 000 &, 000 &, 000 &, 000 \\
\hline & $\mathrm{N}$ & 300 & 300 & 300 & 300 \\
\hline \multirow{3}{*}{$\begin{array}{c}\text { Faktör } 2 \\
\text { (İletişim ve uyumu } \\
\text { Destekleyicilik) }\end{array}$} & $\mathrm{r}$ & &,- 171 &,- 384 &, 873 \\
\hline & $\mathrm{p}$ & & ,003 & ,000 &, 000 \\
\hline & $\mathrm{N}$ & & 300 & 300 & 300 \\
\hline \multirow{3}{*}{$\begin{array}{c}\text { Faktör } 3 \\
\text { (İşlevsizlik) }\end{array}$} & $\mathrm{r}$ & & &,- 370 &,- 214 \\
\hline & $\mathrm{p}$ & & &, 000 &, 000 \\
\hline & $\mathrm{N}$ & & & 300 & 300 \\
\hline \multirow{3}{*}{$\begin{array}{c}\text { Faktör } 4 \\
\text { (Sinırlılık) }\end{array}$} & $\mathrm{r}$ & & & &,- 147 \\
\hline & $\mathrm{p}$ & & & &, 011 \\
\hline & $\mathrm{N}$ & & & & 300 \\
\hline
\end{tabular}


Tablodan da anlaşılacağı üzere ölçeğin alt boyutları arasında anlamlı bir ilişki olup olmadığını belirlemek üzere yapılan Pearson Çarpım Moment korelasyon analizi sonucunda tüm alt boyutlar ve ölçek toplam puanı arasındaki ilişkiler istatistiksel olarak anlamlı bulunmuştur. Alt boyutlar ve toplam puanlar arasındaki söz konusu anlamlılıklar gelişimi kişisel gelişimi destekleyicilik ve iletişim ve uyumu destekleyicilik alt boyutları için pozitif yönde işlevsizlik ve sınırlılık alt boyutları için de negatif yönde gerçekleşmiştir. En düşük anlamlılık ise sınırlılık alt boyutu ile ölçek toplam puanı arasında $\mathrm{p}<, 05$ düzeyinde gerçekleşmiştir. Bu işlemlerin ardından ölçeğin dış tutarlılığını belirlemek amacıyla test-tekrar test korelasyonlarına geçilmiştir.

Tablo 13. Test Tekrar Test Korelasyonlarl

\begin{tabular}{lccc}
\hline \multicolumn{1}{c}{ Faktörler } & $\mathrm{N}$ & $\mathrm{r}$ & $\mathrm{P}$ \\
\hline Faktör 1 (Kişisel Gelişimi Destekleyicilik) & 41 &, 651 &, 000 \\
Faktör 2 (İletişim ve uyumu Destekleyicilik) & 41 &, 701 &, 000 \\
Faktör 3 (İşlevsizlik) & 41 &, 702 &, 000 \\
Faktör 4 (Sınırlılık) & 41 &, 863 &, 000 \\
Toplam & 41 &, 826 &, 000 \\
\hline
\end{tabular}

Tabloda görüldüğü üzere, ölçeğin on iki gün ara ile iki kez uygulanmasından elde edilen puanlar arasındaki ilişkileri belirlemek amacı ile yapılan Pearson korelasyon analizi sonucunda puanlar arasında ilişkiler $\left(\mathrm{r}_{\min }=651 ; \mathrm{r}_{\max }=, 863\right)$ pozitif yönde anlamlı $(\mathrm{p}<, 001)$ bulunmuştur. Yani YDT alt boyut ve toplam puanlarının ölçümlerinde tutarlı olduğu saptanmıştır. Elde edilen tüm bu sonuçlar Eğitimde Yaratıcı Drama Etkinliklerine Yönelik Tutum Ölçeğinin (YDT) kabul edilebilir düzeyde geçerlik ve güvenirlik değerlerine sahip olduğunu ortaya koymaktadır. Eğitimde Yaratıcı Drama Etkinliklerine Yönelik Tutum Ölçeğinin (YDT) son hali ekte sunulmuştur.

\section{Yorum ve Tartışma}

Bu çalışma kapsamında okul yöneticilerinin eğitimde yaratıcı drama etkinliklerine yönelik tutumlarını belirlemeye yönelik geçerli ve güvenilir bir ölçek geliştirilmiştir. Elde edilen bulgular okul yöneticilerinin eğitimde yaratıcı drama etkinliklerine yönelik tutumlarını belirlemede ölçeğin uygun niteliklere sahip olduğunu göstermektedir. Geliştirilen ölçeğin yöneticilerin tutumlarını belirlemede araştırmacı ve eğitimcilere yardımcı olacağ1 ve alan yazına katk1 sağlayacağ1 düşünülmektedir. Öte yandan ilgili literatürde benzer bir ölçek bulunmaması nedeniyle bu çerçevede yürütülecek çalışmalar için, geliştirilen ölçeğin önemli bir referans teşkil edeceği söylenebilir. Eğitimciler tarafından geçerli ve güvenilir biçimde kullanılabilecek bir ölçme aracı olmasından hareketle, geliştirilen ölçeğin okul yöneticilerinin eğitimde yaratıcı drama etkinliklerine yönelik tutumlarını belirlemede etkin bir veri toplama aracı olacağı düşünülmekte ve araştırmacılara önerilmektedir. $\mathrm{Bu}$ çerçevede yöneticilerin tutumlarının belirlenerek çeşitli demografik değişkenler bağlamında incelenmesi, sonuçlarının karşılaştırılması, bundan sonraki araştırmacılara önerilebilir. Ayrıca elde edilen verilerin daha sağlıklı bir şekilde genellenebilirliğini artırmak amacıyla araştırma daha büyük örneklem grupları üzerinde yinelenebilir. 


\section{Kaynakça}

Adıgüzel, H.Ö. (2006). Eğitimde Yeni Bir Yöntem ve Disiplin: Yaratıcı Drama. H.Ö.Adıgüzel (Yay.Haz.).Yaratıcı Drama 1985- 1998 Yazılar içinde (ss.203-222). Ankara: Naturel Yayınları

Baykul, Y. (2000). Eğitimde ve psikolojide ölçme: klasik test teorisi ve uygulaması. Ankara:ÖSYM Yayınları

Büyüköztürk, Ş. (2002). Sosyal Bilimler İçin Veri Analizi El Kitabı. Ankara: Pegem A Yayıncılık.

Büyüköztürk, Ş. (2004). Veri Analizi El Kitabı. Ankara: Pegem A Yayıncılık.

Büyüköztürk, Ş. (2008). Sosyal Bilimler İçin Veri Analizi El Kitabı. Ankara: Pegem A Yayıncılık

Çakır, S.Ö.Şahin, T. ve Şahin, B. (2000). İlköğretim 6. Sınıf Fen Bilgisi Dersine İlişkin Bazı Değişkenlerin Öğrencilerin Duyuşsal Özelliklerini Açıklama Gücü, Hacettepe Üniversitesi Eğitim Fakültesi Dergisi, sayı:19, s.43-49.

Field, A. (2005). Discovering Statistics Using SPSS. London: SAGE Yayınları.

Fulford, J; Hutchinfs, M. ve Shmitz, H. (2001). İlköğretimde Drama. (Leyla Küçükahmet, Hande Borçbakan, S. Sadi Karamanoğlu ,Çev.). Ankara: Nobel Yayınevi.

Güner H. ve diğ., (1999). "Bilim Toplumuna Geçiş Sürecinde Fen Eğitimcisinin Niteliklerine Çağdaş Yaklaşımlar” D.E.Ü. Buca Eğitim Fakültesi Dergisi ,özel say1: 10, s.412-421.

Güneysu, S. (1991). Eğitimde Drama H.Ömer Adıgüzel (Yay.Haz) Yaratıcı Drama 1985- 1995 Yazılar içinde(ss.95-101). Ankara :Naturel Kitap Yayıncilı.

Kalaycı, Ş. (2006). SPSS Uygulamalı Çok Değişkenli İstatistik Teknikleri, Ankara: Asil Yayıncılık.

Lawshe, C. H. (1975). “A quantitative approach to content validity.” Personnel Psychology, 28, 563-575.

Okvuran, A. (1994). Yaratıı Drama Eğitiminin Empatik Beceri ve Empatik Eğilim Düzeylerine Etkisi.H.Ö. Adıgüzel(Yay. Haz).Yaratıcı Drama 1985- 1995 Yazılar içinde (ss.231-244) Ankara:Naturel Kitap Yayıncılık

Ömeroğlu, E. (1990). Anaokuluna Giden Beş-altı Yaşındaki Çocukların Sözel Yaratııılıklarının Gelişiminde Yaratıcı Drama Eğitiminin Etkisi. Yayımlanmamış doktora tezi, Hacettepe Üniversitesi, Ankara.

Özgüven, İ. E. (1999), Psikolojik Testler. (3.b.s). Ankara: PDREM Yayınları.

San, İ. (1991). Eğitim-Öğretimde Yaşayarak-Öğrenme Yöntemi ve Estetik Süreç Olarak Yaratıı Drama. İ. Fındıkçı (Yay. Haz.). Eğitimde Nitelik Geliştirme içinde (ss.261-265) İstanbul: Kültür Koleji Yayınları.

San, İ. (1989). Eğitimde Yaratıcı Drama. H.Ö Adıgüzel(Yay.Haz).Yaratıcı Drama(1985- 1995 yazılar) içinde (ss.57-69) Ankara: Naturel Kitap Yayıncılık

Sherif, M. ve Sherif, C. W. (1996). Sosyal Psikolojiye Giriş II. (Mustafa Atakay ve Aysun Yılmaz,Çev). İstanbul: Sosyal Yayınlar.

Üstündağ, T. (1994). Günümüz Eğitiminde Dramanın Yeri ,Yaşadıkça Eğitim DergisiSayı :37 7-10

Tabachnick, B.G. ve Fidell, L.S. (1996). Using multivariate statistics. New York: HarperCollins College

Tavşancıl, E. (2002) Tutumların Ölçülmesi ve SPSS ile Veri Analizi. Ankara:.Nobel Yayınları

Yeğen, G. (2004). Eğitim Fakültelerindeki Yaratıcı Drama Eğitimi. Türkiye'de Drama Liderleri Buluşması ve 6. Ulusal Drama Semineri Kitabı. Ankara: Drama Liderliği Oluşum Yayınları Fersa Matbaacılık 
EK

Okul Yöneticilerinin Eğitimde Yaratıcı Drama Etkinliklerine Yönelik Tutum Ölçeği (YDT)*

\begin{tabular}{|c|c|c|c|c|c|c|}
\hline $\begin{array}{l}\text { Yeni } \\
\text { No }\end{array}$ & İfadeler (orijinal madde numaraları ile) & 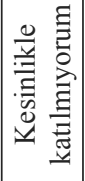 & 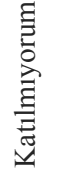 & 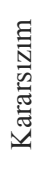 & 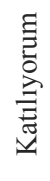 & 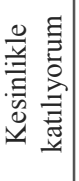 \\
\hline & 2. Kimlik gelişiminde, eğitimde yaratıcı dramanın önemli olduğunu düşünmüyorum. & (1) & (2) & (3) & (4) & (5) \\
\hline & 3. Öğretmenleri eğitimde yaratıcı drama ile ilgili hizmet içi eğitim almaya yönlendiririm. & (1) & (2) & (3) & (4) & (5) \\
\hline & $\begin{array}{l}\text { 4. Eğitimde yaratıcı dramanın bireyin sosyal ilişkilerini zenginleştirebileceğini } \\
\text { düşünmüyorum. }\end{array}$ & (1) & (2) & (3) & (4) & (5) \\
\hline & $\begin{array}{l}\text { 5. Eğitimde yaratııı dramanın kendini gerçekleştirme sürecinin bir aşaması olduğu } \\
\text { düşüncesindeyim. }\end{array}$ & (1) & (2) & (3) & (4) & (5) \\
\hline & $\begin{array}{l}\text { 6. Eğitimde yaratıcı dramanın sosyalleşme sürecinde öğrencilere yardımcı olduğunu } \\
\text { düşünüyorum. }\end{array}$ & (1) & (2) & (3) & (4) & (5) \\
\hline & $\begin{array}{l}\text { 7. Eğitimde yaratıcı dramanın içerik ve amaçlarını ilgililere anlatacak birikime sahip olmak } \\
\text { isterim. }\end{array}$ & (1) & (2) & (3) & (4) & (5) \\
\hline & $\begin{array}{l}\text { 8. Okulda, eğitimde yaratıcı dramaya izin vererek öğrencinin demokrasi bilincini } \\
\text { benimsemesine katkı sağlarım. }\end{array}$ & (1) & (2) & (3) & (4) & (5) \\
\hline & $\begin{array}{l}\text { 9. Eğitimde yaratıcı dramanın bireyin duygularını daha iyi tanımasını sağladığını } \\
\text { düşünüyorum. }\end{array}$ & (1) & (2) & (3) & (4) & (5) \\
\hline & $\begin{array}{l}\text { 10. Eğitimde yaratıcı dramanın insani değerlerin gelişmesine katkısı olduğunu } \\
\text { düşünmüyorum. }\end{array}$ & (1) & (2) & (3) & (4) & (5) \\
\hline & 11. Eğitimde yaratııı dramanın amaçlarının sınıflarda gerçekleşeceğini düşünmüyorum. & (1) & (2) & (3) & (4) & (5) \\
\hline & 13. Eğitimde yaratıcı drama çocuğun lehine sonuçlar doğurur. & (1) & (2) & (3) & (4) & (5) \\
\hline & $\begin{array}{l}\text { 14. Öğrenciler arasındaki problemlerin çözümünde eğitimde yaratııı dramanın yöntem } \\
\text { olarak kullanılabileceği kanaatindeyim. }\end{array}$ & (1) & (2) & (3) & (4) & (5) \\
\hline & $\begin{array}{l}\text { 15. Öğrenci tanıma çalışmalarında rehber öğretmenlerin eğitimde yaratıcı drama } \\
\text { etkinliklerinden yararlanmasını teşvik ederim. }\end{array}$ & (1) & (2) & (3) & (4) & (5) \\
\hline & 16. Eğitimde yaratıcı dramanın çocuk eğitimine katkısı çok fazladır. & (1) & (2) & (3) & (4) & (5) \\
\hline
\end{tabular}

* $\quad$ Araştırmacıdan izin alınmadan ölçek kullanılamaz.. 


\begin{tabular}{|c|c|c|c|c|c|c|}
\hline $\begin{array}{l}\text { Yeni } \\
\text { No }\end{array}$ & İfadeler (orijinal madde numaraları ile) & 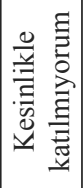 & 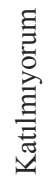 & 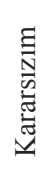 & 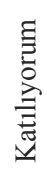 & 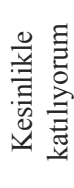 \\
\hline & $\begin{array}{l}\text { 17. Eğitimde yaratıcı dramanın, öğrencilerin ilişkilerinde empatiyi etkin olarak } \\
\text { kullanmalarını sağladığını düşünüyorum. }\end{array}$ & (1) & (2) & (3) & (4) & (5) \\
\hline & 18. Eğitimde yaratıcı dramanın bireydeki farkındalığı arttırdığını düşünüyorum. & (1) & (2) & (3) & (4) & (5) \\
\hline & 19. Eğitimde yaratıcı drama gösteriden başka bir şey değil. & (1) & (2) & (3) & (4) & (5) \\
\hline & 20. Eğitimde yaratıcı drama öğrencilerin daha sağlıklı bir bireyler olmalarına yardımcı olur. & (1) & (2) & (3) & (4) & (5) \\
\hline & 21. Eğitimde yaratıcı dramanın, okulda zorbalık eğilimlerini azaltacağını düşünüyorum. & (1) & (2) & (3) & (4) & (5) \\
\hline & $\begin{array}{l}\text { 22. Eğitimde yaratıcı dramanın öğrencilerin ifade edemediği sorunlarını ortaya çıkaran bir } \\
\text { araç olduğunu düşünüyorum. }\end{array}$ & (1) & (2) & (3) & (4) & (5) \\
\hline & $\begin{array}{l}\text { 23. Eğitimde yaratıcı dramanın bireyin kendini daha iyi tanımasını sağladığını } \\
\text { düşünüyorum. }\end{array}$ & (1) & (2) & (3) & (4) & (5) \\
\hline & 24. Okulda eğitimde yaratıcı drama sosyal çatışmaları çözmede prova işlevi üstlenebilir. & (1) & (2) & (3) & (4) & (5) \\
\hline & $\begin{array}{l}\text { 25. Eğitimde yaratıcı drama etkinliklerinin okuldaki disiplin sorunlarının azalmasında etkili } \\
\text { olacağını düşünmüyorum. }\end{array}$ & (1) & (2) & (3) & (4) & (5) \\
\hline & 26. Eğitimde yaratıcı dramanın sadece çocuklara yönelik olabileceğini düşünüyorum. & (1) & (2) & (3) & (4) & (5) \\
\hline & 27. Okulda, eğitimde yaratıcı dramayı, seçmeli ders olarak okutulması için öneririm. & (1) & (2) & (3) & (4) & (5) \\
\hline & 28. Dersinde, eğitimde yaratıcı drama uygulayan öğretmeni desteklerim. & (1) & (2) & (3) & (4) & (5) \\
\hline & 30. Okul kütüphanesindeki eğitimde yaratıcı drama yayınlarının sayısının artması gerekir. & (1) & (2) & (3) & (4) & (5) \\
\hline & $\begin{array}{l}\text { 31. Zor öğrenciler için planlanan eğitim programında eğitimde yaratıcı drama çalışmalarına } \\
\text { yer verilmesini öneririm. }\end{array}$ & (1) & (2) & (3) & (4) & (5) \\
\hline & $\begin{array}{l}\text { 32. Öğrencilerin eğitimde yaratıcı drama etkinliklerine ilgisini arttırıcı çalışmalar } \\
\text { yapılmasını desteklerim. }\end{array}$ & (1) & (2) & (3) & (4) & (5) \\
\hline & $\begin{array}{l}\text { 33. Öğrenciler arasındaki sorunların çözümünde eğitimde yaratıcı drama etkinliklerinden } \\
\text { yararlanılmasını teşvik ederim. }\end{array}$ & (1) & (2) & (3) & (4) & (5) \\
\hline
\end{tabular}




\title{
The Work of Scale Development of School Directors about TheirAttitudes Related to Creative Drama Activities in School Education
}

\author{
Mustafa Otrar ${ }^{3}$ \\ Adnan Çöme

\section{Introduction}

The reflections of the method in the field of manager is new and the attitudes towards drama in different levels and age groups are point of interest. A qualified school manager who is supposed to have scientific attitude and scientific process abilities is inavitable to be efficient in the education process when he also adopts personal characteristics that would be model (Özbilgin, 1989; Akt:Güner\&diğ.,1999)

Especially ; change providing in learning within doing and experiencing for students and moreover the learning of students with the practices which they describe as funny and enjoyable; the drama studies of which reflections in school management are newly strenghtening are increasing interest towards the question of using such a technique.

So the managers have an important role in application of educational drama in schools .Administrator approaches; especially; in running decision mechanism in applications; in coordinating the staff and the properly arranging and checking of the education stages are effective. Another administrative feature of educational drama facilities; that are distinctive, are the attitudes and perception of the managers towards the said activities. In education; the use of creative drama activities will be affected by the attitudes of the educational manager in one dimension. It is important that the managers who have positive attitudes are supported in terms of forming school facilities and staff's using these facilities.

For this reason; to form a relation between the theoric content of the study; the creative drama activities that are being used in schools and the attitudes of managers towards these activities; a measurement implementation has been used towards the school managers in private and public primary schools in accordance with the application of creative dramas in schools and accomplishing and evaluating the creative drama.

\section{Method}

\section{Study Group}

300 managers (managers and assistant managers) working in 114 primary school who are chosen with the technique of random stack modelling from the official and private primary schools which are connected with the Ministry of National Education in İstanbul; forms the sample of the research.

\section{Procedure}

In the process of improving measurement; in the frame of related litterateur; A steps pool was prepared including 61 items and the results were evaluated by the Lawshe technique by appealing to Authority opinions ( 7 Authorities). At last, it has been decided that the measurement outline is formed by 37 items. After determining

$5 \quad$ Ph. D., Marmara University Atatürk Education Faculty, motrar@marmara.edu.tr

6 Teacher, Ministry Education, adnancome@gmail.com 
the convenience rates with Kaiser-Meyer Olkin $(\mathrm{KMO}=, 951)$ and Barttlett $(\mathrm{p}<, 001)$ tests; we passed to the factor analysis processes. Its last form scale consists of 30 steps.

\section{Results}

Like this, in the factor analysis becoming in 3 steps, it was determined that 1 eigen rate and scale shows a structure with 4 factors which has the load of \%45,11 in highest degree and \%3,43 in the lowest degree. The occurring factors were called; "promoting the personel development", "promoting the communication and adjustment , "uselessness", and "nonfunctionality" acording to their included steps. And, it has been pointed out that the given total variance is about 0,63 and thus, there has been significant correlations among factors. It has been displayed that the items were discriminating and the item-total and item-reminder correlations were significant. At the end of the survey, Cronbach's Alpha coefficient has been calculated as 0,909 total. Test-retest correlations has been found significant for all factors $\left(\mathrm{r}_{\min }=, 651 ; \mathrm{p}<, 001 / \mathrm{r}_{\max }=, 863 ; \mathrm{p}<, 001\right)$ and scale total point $(\mathrm{r}=, 826 ; \mathrm{p}<, 001)$.

\section{Discussion}

The valid and reliable scale that is intended to determine school administrators' attitude towards creative drama activities in education was developed within the scope of this work. Obtained findings illustrate that the scale which determines school administrators' attitude towards creative drama activities in education has favorable quality. The reformed scale is thought to assist in determining the administrators' attitude to researchers and academicians and body of literature. On the other hand, the reformed scale can be determined as an important reference because of absence of a scale in related literature. The reformed scale is thought as an effective data collection tool and recommended by academicians. Analyzing the context of various demographical variables by determining the administrators' attitude can be recommended next researchers. In addition, the research can be repeated on larger sample groups for aiming to increase generalizability. 